\title{
Penerapan Arsitektur Berwawasan Lingkungan pada Rancangan Sentra Bordir di Kabupaten Pasuruan Jawa Timur
}

\author{
Ahmad Fahmi Fatchur Rizal ${ }^{1}$, Wiwik Widyo Widjajanti ${ }^{2}$, Randy Pratama Salisnanda ${ }^{3}$ \\ 1,2,3 Jurusan Arsitektur, Fakultas Teknik Sipil dan Perencanaan \\ Institut Teknologi Adhi Tama Surabaya \\ Email: fahmirizal485@gmail.com
}

\begin{abstract}
Pasuruan is famous for top products of embroidery that are resulted by Small and Medium Industries. The production of embroidery has widely spread in all districts of Pasuruan Regency, particularly in Bangil District. Embroidery refers to ornaments attached on the clothes or other materials made by needle and thread. It also belongs to one of ornamental craft varieties (clothes accessory) which focuses on the beauty and competition of thread colors on the clothes as the media supported by a set of sewing kits (embroidery sewing machine) or computerizedembroidery sewing machine. The ornament of embroidery can use not only thread but also other materials such as metal pieces, pearls, beads, bird feather, and sequins. Planning and designing Embroider Centre are intended for providing a place of production and marketing upon craft products as well as supporting other activities such as the centre of promotion, information, and cultural education, which later on, it can become a tourism potential which is beneficial for developing the local and economy of Pasuruan society. The use of sustainable architecture theme in designing this building is expected to present a certain character or identity of facility and gallery. Besides, sustainable architecture also emphasizes on the surrounding environment such as conserving energy, working climate, respect for site, respect for user, and holistic. The designing process of building architecture was carried out through a series of stages beginning from project identification, precedent study, design program, design concept, and design development.
\end{abstract}

Keywords: Embroidery, Embroidery Centre, Sustainable Architecture

\begin{abstract}
Abstrak. Pasuruan ini memiliki produk IKM yang menjadi produk unggulan yaitu bordir. Produksi bordir tersebar luas di seluruh Kabupaten Pasuruan, terutama di Kecamatan Bangil. Bordir merupakan hiasan diatas kain atau bahan- bahan lain dengan jarum jahit dan benang. Bordir juga bisa didefinisikan sebagai salah satu kerajinan ragam hias (untuk aksesoris busana) yang menitik beratkan pada keindahan dan kompetisi warna benang pada medium berbagai kain dengan alat bantu seperangkat mesin jahit (mesin jahit bordir) atau mesin jahit bordir komputer. Selain benang, hiasan untuk sulaman atau bordir dapat menggunakan bahan-bahan seperti potongan logam, mutiara, manik-manik, bulu burung, dan payet. Perencanaan dan Perancangan Sentra Bordir ini memiliki tujuan yaitu sebagai tempat produksi dan pemasaran hasil kerajinan serta adanya aktivitas lain diantaranya adalah pusat promosi, informasi, budaya edukasi sehingga nantinya mampu menjadi potensi wisata yang dapat memberi manfaat bagi pengembangan daerah dan ekonomi masyarakat diKabupaten Pasuruan. Penggunaan tema Arsitektur Berwawasan Lingkungan dalam perancangan bangunan ini diharapkan dapat menampilkan suatu karakter atau identitas dari fasilitas dan galeri itu sendiri, tidak hanya itu Arsitektur Berwawasan Lingkungan juga mengedepankan lingkungan sekitarnya meliputi conserving energy, working climate, respect for site, respect for user, holistic. Perancangan arsitektur bangunan dilakukan melalui serangkaian tahapan mulai dari identifikasi proyek, studi preseden, program rancangan, konsep hingga pengembangan rancangan.
\end{abstract}

Kata Kunci: Bordir, Sentra Bordir, Arsitektur Berwawasan Lingkungan

\section{Pendahuluan}

Kabupaten Pasuruan tepatnya dikecamatan Bangil mempunyai akronim Bangil Kota Bordir atau Bang Kodir, istilah Bang Kodir pertama muncul pada tahun 2005 yang dimotori oleh Pemerintah Kabupaten Pasuruan dan Asosiasi Pengusaha Bordir (ASPENDIR). ASPENDIR ini merupakan asosiasi yang berisikan para pengusaha bordir diseluruh Kab. Pasuruan. Bangil yang salah satu kecamatan potensial diKabupaten Pasuruan, sejak dahulu sudah dikenal merupakan sentra para perajin bordir, 
setidaknya di Jawa Timur. Ragam karya seni menghias kain ini sudah lama ditekuni masyarakat setempat, dan puncaknya semakin terasa sejak negeri ini diterpa badai krisis moneter Tahun 1997.

Bordir bangil lebih bersifat tradisional, produksinya tidak benar- benar massal. Berarti dari sekian pengusaha yang memproduksi kain bordir mmpunyai model dan desain masing - masing. Kelebihan ini sangat menguntungkan bagi pasar. Sehingga produk bordir bangil yang beredar dipasaran lebih bragam. Kekhasan lainnya adalah pada beberapa coraknya. Desain dengan tema alami pada bordir lebih kentara. Gambar - gambar bunga sedap malam, yang juga khas Pasuruan banyak menjadi inspirasi. Selain itu model kerawang atau lubang -lubangnya juga khas (Alim,2005).

Industri bordir sebagai kompetensi inti Industri Daerah harus selalu dikembangkan dan dikuatkan karena memiliki dampak besar bagi pembangunan ekonomi didaerah dan nasional. Adanya kompetensi inti ini, penduduk diwilayah tersebut akan menjadi ahli, setelah produk bordir ini menjadi kompetensi inti dari wilayah tersebut, maka mereka dapat memproduksi produk dengan kualitas tinggi dengan harga yang dapat dijangkau oleh seluruh lapisan masyarakat, dengan kata lain membuat Kabupaten Pasuruan memiliki spesialisasi dibidang bordir.

Oleh karena itu, untuk memberikan wadah kepada pelaku industri bordir dan dibuatkan suatu bangunan untuk mengembangkan industri bordir skala rumahan menjadi industri bordir skala besar yaitu dengan memberikan wadah atau tempat untuk produksi dan pemasaran hasil kerajinan serta adanya aktivitas lain diantaranya adalah pusat promosi, informasi, budaya edukasi sehingga nantinya mampu menjadi potensi wisata yang dapat memberi manfaat bagi pengembangan daerah dan ekonomi masyarakat yang berlokasi di Kabupaten Pasuruan Jawa Timur.

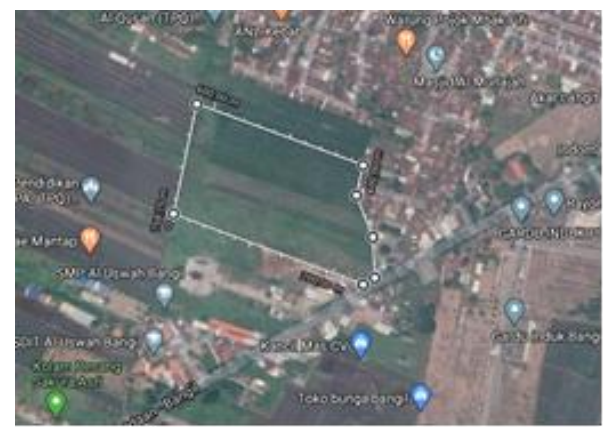

Gambar 1. Peta Lokasi

\section{Kajian Pustaka}

Pada bangunan ini konsep yang digunakan green architecture atau arsitektur hijau memiliki sifat sifat seperti suistanable atau berkelanjutan, earthfriendly atau ramah lingkungan, dan high performance building. Dalam buku "Green Architecture Design for a sustainable future" karya Brenda dan Robert Vale (1996), terdapat prinsip - prinsip yang digunakan untuk mendesain sesuai konsep green architecture antara lain :

a. Conserving Energy (hemat energi) yang merupakan sebuah prinsip untuk menghemat penggunaan energi pada suatu bangunan, seperti optimalisasi perolehan sinar matahari pada siang hari untuk meminimalisir penggunaan lampu serta meminimalisir penggunaan pendingin ruangan dengan optimalisasi penghawaan alami, yang mana akan mengantarkan pada perilaku hemat energy listrik.

b. Working Climate, atau menyesuaikan iklim adalah prinsip yang memanfaatkan kondisi alam, iklim dan lingkungan sekitar kedalam desain dan operasional bangunan seperti orientasi bangunan, menggunakan elemen tumbuhan dan air untuk menciptakan iklim mikro, serta desain jendela atau atap yang dapat digunakan untuk terjadinya cross ventilation.

c. Respect for Site, atau menanggapi keadaan tapak yaitu prinsip untuk memperhatikan kondisi di dalam dan sekitar tapak untuk menjadi pertimbangan dalam sebuah desain bangunan agar tidak merusak lingkungannya seperti mempertahankan kondisi tapak, penggunaan material ramah lingkungan. 
d. Respect for User, merupakan hal yang terpenting dalam sebuah perancangan bangunan, untuk tetap memperhatikan pengguna atau user bangunan sesuai dengan kebutuhan dan keinginannya.

e. Limiting New Resources, merupakan prinsip yang mengharuskan sebuah bangunan untuk menggunakan material yang telah tersedia sehingga dapat meminimalkan penggunaan material baru.

f. Holistic, atau keseluruhan memiliki pengertian untuk selalu mendesain bangunan dengan menerapkan prinsip green architecture yang saling berkaitan secaramenyeluruh dan sesuai dengan kebutuhan dalam proses mendesain dan menyesuaikan dengan kondisi dan potensi yang terdapat dalam site.

\subsection{Pengertian Judul}

Menurut kamus besar bahasa Indonesia sentra adalah tempat yang letaknya dibagian tengahatau bisa disebut pusat, pusat yang dimaksud adalah sebagai tempat utama dari produksi bordir. Bordir merupakan sebuah seni yang memadukan dekorasi sulaman pada kain dengan menggunakan alat bantu jarum dan benang. Bordir merupakan suatu ungkapan rasa yang memiliki nilai artistik yang memiliki kepuasan batin. Namun sesuai dengan bergulirnya waktu dalam tempaan situasi dan kondisi, bordir menjadi salah satu komoditas perdagangan yang diminati hingga kini.

Suhersono (dalam Budiastuti, 2013) menyatakan bahwa istilah bordir identik dengan menyulam, karena kata 'bordir' diambil dari kata istilah Inggris 'embroidery', yang artinya sulaman. Dengan menggunakan jari-jemari tangan kedua alat ini ditusuk-tusukkan pada kain, lalu muncullah berbagai istilah berbagai jenis tusuk, yang pada akhirnya disebut dengan istilah sulam.

Berdasarkan pemaparan di atas, dapat ditarik pemahaman bahwa bordir adalah teknik pembuatan motif pada permukaan kain dengan cara membuat tusuk- tusuk hias dari benang. Sedangkan seni kerajinan bordir adalah kegiatan yang menghasilkan produk-produk bordiran atau usaha pembuatan produk dengan menggunakan teknik bordir.

Bordir pada zaman dahulu menggunakan yang disebut dengan sulam, namun dengan kemajuan teknologi dan perkembangan zaman bordir kini menggunakan mesin bordir manual bahkan sekarang mesin bordir dengan menggunakan komputer. Mesin bordir komputer lebih canggih pengerjaannya.

\subsection{Studi Preseden}

Studi preseden atau studi banding merupakan suatu kegiatan yang dilakukan dengan cara menentukan objek atau lokasi sebagai pembanding terhadap apa yang diketahui oleh pengamat untuk dilakukan tinjauan dengan tujuan mendapatkan informasi yang menjadi referensi perancangan bangunan. Studi ini dilakukan dengan cara studi banding lapangan dan studi banding literatur.

Studi banding lapangan merupakan kegiatan meninjau suatu objek secara langsung dilokasi untuk mengetahui bagaimana keadaan dan dan kondisi objek yang sebenarnya. Penulis melakukan studi banding lapangan sehingga diperoleh gambaran beberapa fasilitas terkait judul tersebut. Berikut beberapa studi banding lapangan yang dipilih dari beberapa obyek: (1) Faiza Bordir (2) Sentra Produk Unggulan, Bangil.

Studi banding literatur adalah kegiatan mempelajari suatu objek untuk memperoleh data yang bersumber dari pustaka berupa buku, majalah atau artikel diinternet yang akurat dan terpercaya. Penulis mengadakan studi literature terkait judul untuk melengkapi kekurangan yang didapat dari studi lapangan dan juga studi literature terkait tema arsitektur berwawasan lingkungan (1) The Interlace, Singapore (2) Ng Teng Fong General Hospital dan Jurong Community Hospital, Singapore (3) Industri Bordir Tasikmalaya (4) DEVITRI Sentra Bordir (5) Dahlia Bordir

Dari beberapa studi kasus diatas, kemudian dianalisa dan diambil kesimpulan, Tabel 1 berikut beberapa kelebihan dan kekurangan:

Tabel 1. Kelebihan dan Kekurangan Obyek Studi Preseden

\begin{tabular}{|c|l|l|}
\hline No. & Kelebihan & Kekurangan \\
\hline 1 & $\begin{array}{l}\text { Industri bordir tasikmalaya pola tatanan lahan menggunakan pola } \\
\text { linier dimana pola ini memiliki sirkulasi yang jelas dan terarah. }\end{array}$ & $\begin{array}{l}\text { Tatatan lahannya masih sangat statis dan kesannya masih } \\
\text { monoton dan untuk penataan area parkir sendiri kurang jelas. }\end{array}$ \\
\hline 2 & $\begin{array}{l}\text { Bangunan sentra produk unggulan bentuk bangunan menyerupai } \\
\text { persegi terlihat seperti bangunan formal }\end{array}$ & $\begin{array}{l}\text { Bangunan tersebut kurang mencerminkan lambang atau bentuk } \\
\text { bangunana sentra bordir jadi kurang menarik }\end{array}$ \\
\hline
\end{tabular}




\begin{tabular}{|c|l|l|}
\hline No. & Kelebihan & Kekurangan \\
\hline 3 & $\begin{array}{l}\text { Faiza bordir Ruang terbentuk karena disesuaikan dengan fungsi } \\
\text { dan zoning ruang. }\end{array}$ & $\begin{array}{l}\text { Ketinggian elevasi pada ruang yang pendek akan terlihat } \\
\text { ruagan tersebut kecil }\end{array}$ \\
\hline 4 & $\begin{array}{l}\text { Devitri Sentra bordir Bangunan tersebut sesuai dengan ukuran } \\
\text { site jadi tempat parkir berada dicarport layaknya rumah }\end{array}$ & $\begin{array}{l}\text { Tempat parkir hanya bisa digunakan untuk kendaran dua mobil } \\
\text { tidak ada space untuk kendaraan banyak }\end{array}$ \\
\hline 5 & $\begin{array}{l}\text { Dahlia bordir Pola yang digunakan adalah pola linier dimana dari } \\
\text { ME menuju lurus ke SE. Pola seperti ini bertujuan agar } \\
\text { pengunjung bisa melihat semua fasilitas yang ada }\end{array}$ & $\begin{array}{l}\text { Parkir kendaran masih berada disembrang tempat tanpa ada } \\
\text { tanda batas parkir. }\end{array}$ \\
\hline
\end{tabular}

\section{Metode Penelitian}

Metode yang diterapkan pada perancangan ini berdasarkan metode deskriptif. Dalam metode tersebut akan dilakukan kegiatan observasi objek studi pada masa sekarang untuk mendapatkan gambaran secara akurat berdasarkan fakta-fakta yang ada. Kemudian akan dilakukan kegiatan wawancara kepada narasumber yang terkait dengan objek studi untuk mendapatkan informasi tambahan atau bukti yang memperkuat informasi yang telah ada. Selanjutnya dilakukan pengolahan data dari hasil observasi kemudian dilanjutkan penyusunan konsep, penentuan konsep rancangan, dan terakhir studio tugas akhir sebagai proses pembuatan gambar desain arsitektural.

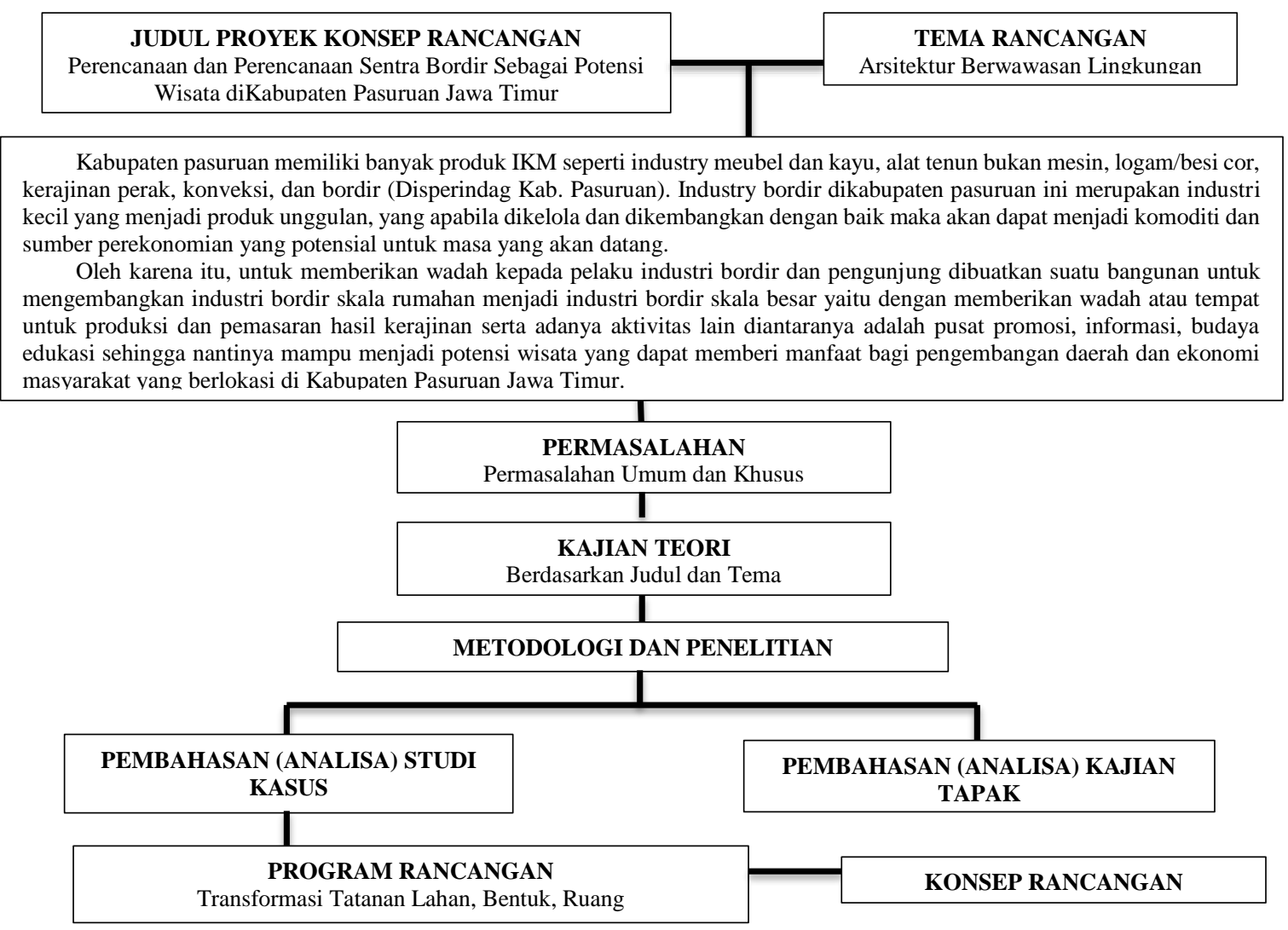

Gambar 2. Diagram Penelitian

\section{Hasil dan pembahasan}

Pemrograman dalam arsitektur dapat dikatakan sebagai proses menggali fakta-fakta hingga menetapkan kebutuhan-kebutuhan klien. Di dalam proses ini terdapat sejumlah pertimbanganpertimbangan seperti fungsi (ruang termasuk didalamnya), bentuk, ekonomi hingga waktu. Berbicara mengenai pertimbangan fungsi, berarti secara tidak langsung berkenaan dengan masalah ruang. Maka program ruang pada dasarnya adalah menetapkan kebutuhan ruang yang dapat memenuhi kebutuhan dan tuntutan klien. 


\subsection{Program Ruang}

Setelah mengkaji studi literatur yaitu disetiap studi kasus mempunyai kelebihan dan kekurangan masing - masing dari segi program ruang pada kelima objek tersebut. Oleh karena itu, sebagai hasil dari kajian berikut akan digunakan sebagai referensi dan koreksi yang ditujukan kepada proses dari perencanaan dan perancangan Sentra Bordir Sebagai Potensi Wisata diKabupaten Pasuruan Jawa Timur. Di mana komplek Sentra Bordir ini nanti mampu menjadi wadah bagi para pecinta kerajian bordir diPasuruan.

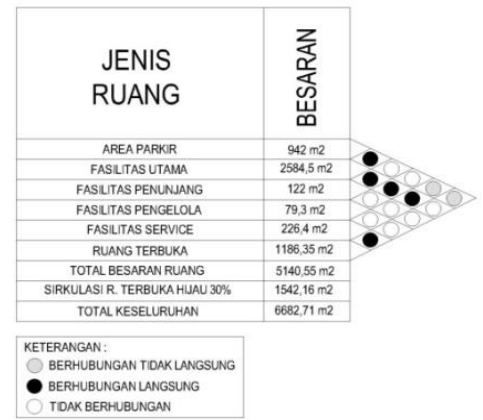

Gambar 3. Kebutuhan Ruang dan Besaran Ruang

\subsection{Konsep dan Transformasi}

Perancangan Pusat kerajinan ini memiliki tujuan yaitu sebagai tempat produksi dan pemasaran hasil kerajinan serta adanya aktivitas lain diantaranya adalah pusat promosi, informasi, budaya edukasi. Tema Arsitektur Berwawasan Lingkungan menjadi tema yang diterapkan karena sesuai dengan kondisi wilayah Kabupaten Pasuruan yang kaya akan kegiatan industri kecil sampai industri skala besar. Tujuannya bahwa bangunan dirancang untuk mengurangi dampak keseluruhan lingkungan binaan terhadap kesehatan manusia dan lingkungan alam dengan lingkungan dari bangunan. Istilah "Bangunan Berkelanjutan" ini dapat didefinisikan sebagai konsep mempertahankan sumber daya alam agar bertahan lebih lama, yang dikaitkan dengan umur potensi vital sumber daya alam dan lingkungan ekologis manusia, seperti sistem iklim planet, sistem pertanian, industri, kehutanan, arsitektur dan juga memenuhi kebutuhan generasi sekarang tanpa mengorbankan kemampuan generasi mendatang untuk memenuhi kebutuhan mereka.

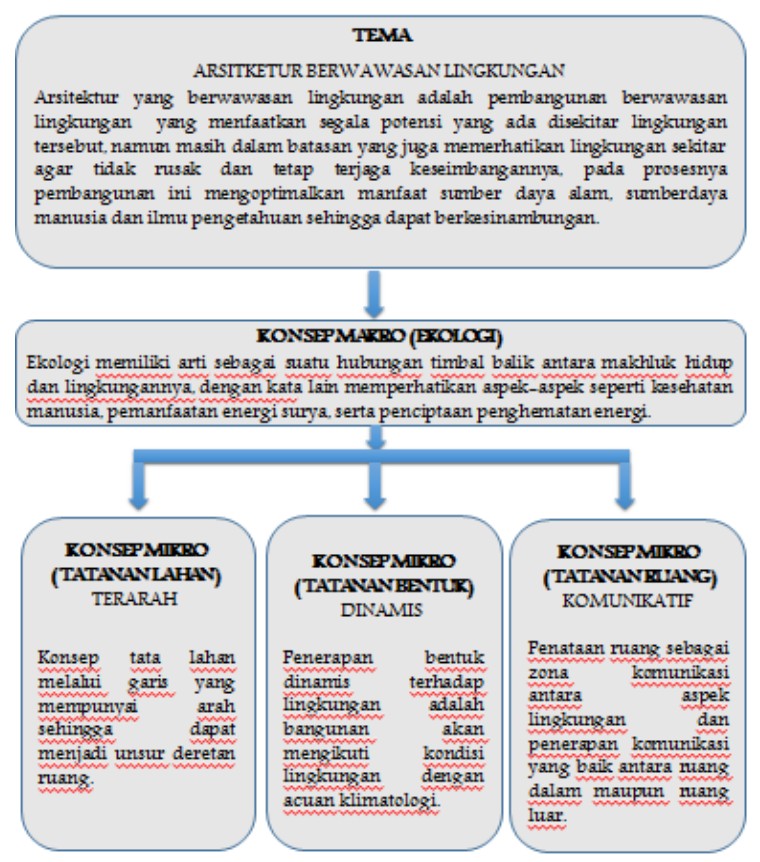

Gambar 4. Diagram Konsep Rancangan 


\subsection{Konsep Makro}

Konsep makro dalam perancangan sentra bordir ini hemat energi merupakan sebuah prinsip untuk menghemat penggunaan energi pada suatu bangunan dengan cara mengoptimalkan masuknya sinar matahari pada siang hari sehingga menghemat dalam penggunaan lampu dan energi listrik serta meminimalkan penggunaan pendingin ruangan. Pembentukan gedung memanfaatkan segala sesuatu yang dapat menurunkan suhu yang dapat dilakukan dengan cara memperhatikan arah orientasi bukaan dinding terhadap sinar matahari.

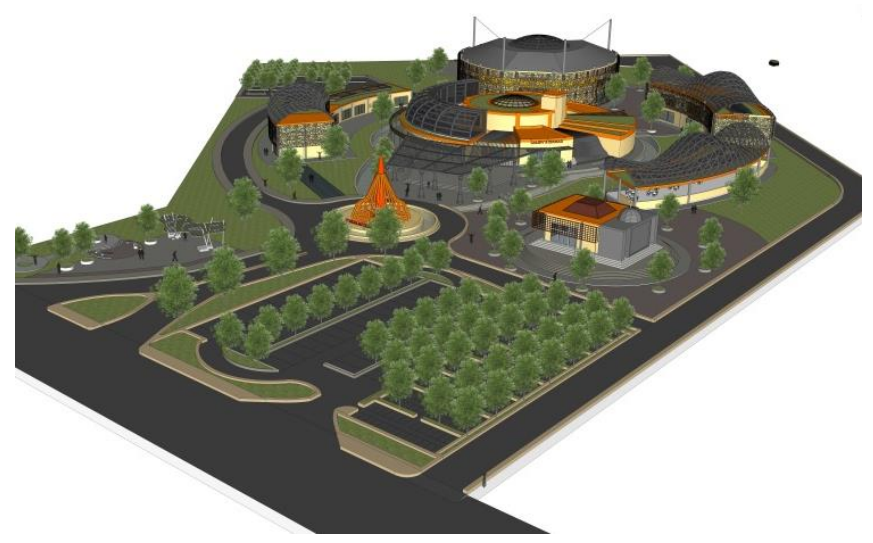

Gambar 5. View Mata Burung

\subsection{Konsep Mikro (Tatanan Lahan)}

Pada aspek tatanan lahan, konsep yang diangkat ialah pendekatan dalam menata lahan dengan menerapkan pola sirkulasi terpusat hal ini untuk mempermudah akses sirkulasi dan juga memerhatikan kondisi dan keadaan lingkungan di sekitar. Dalam konsep ini perancangan tata lahan akan memerhatikan potensi alam yang ada seperti memanfaatkan pohon eksisting untuk digunakan sebagai peneduh lahan parkir atau mengurangi penggunaan perkerasan yang bisa berdampak pada peningkatan suhu lingkungan serta menjadi penyumbang dampak global warming. Pendekatan tersebut dilakukan sebagai bentuk pengingatan dan perenungan manusia terhadap penciptaan alam sebagai salah satu bukti tanda-tanda kebesaran-Nya. Konsep tata lahan yang menuangkan elemen-elemen alam ke dalam rancangan bangunan seperti memanfaatkan cahaya matahari, aliran udara, pohon-pohon yang rindang, gemercik air, dan sebagainya.

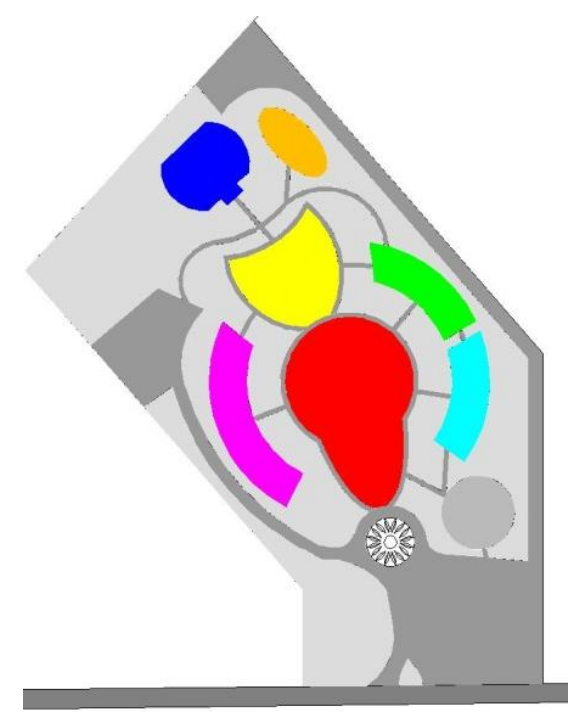

(a)

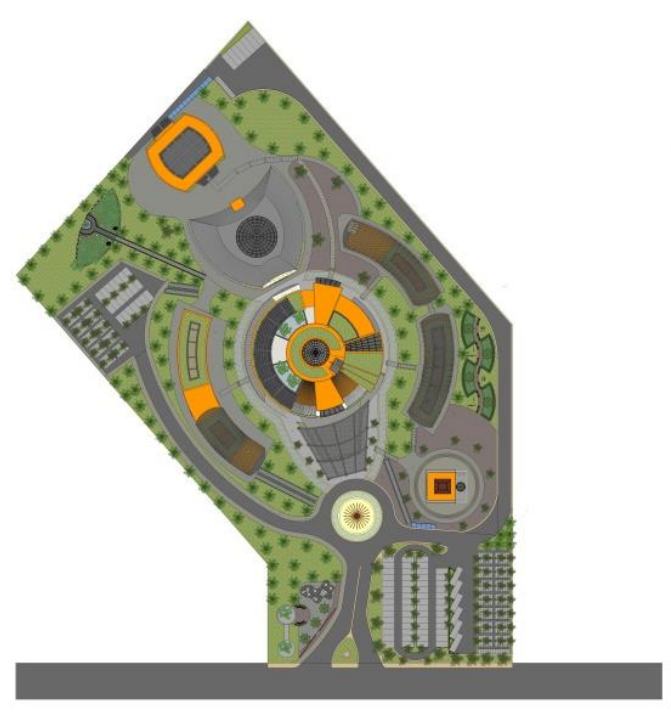

(b)

Gambar 6. (kiri) Rencana Tatanan Lahan; dan (kanan) LahanTatanan Lahan 


\subsection{Konsep Mikro (Tatanan Bentuk)}

Pada konsep mikro bentuk pendekatan yang dilakukan adalah dengan cara merancang tampilan bangunan yang menggunakan bentuk persegi panjang karena memilki bentuk linier dan dinamis. Dinamis memiliki arti penuh semangat dan tenaga. Sehingga, cepat bergerak dan menyesuaikan diri dengan keadaan serta mengandung dinamika. Dinamis dalam arsitektur merupakan sebuah semangat dan tenaga yang diterapkan ketika seorang arsitek akan mendesain sebuah bangunan serta penataan ruang -ruang yang ada didalamnya. Dinamis juga dapat mempertimbangkan kondisi lingkungan hidup antara unsur alam dan lingkungan sekitar pada saat mendesain suatu bangunan yang sesuai dengan keselarasan jiwa.

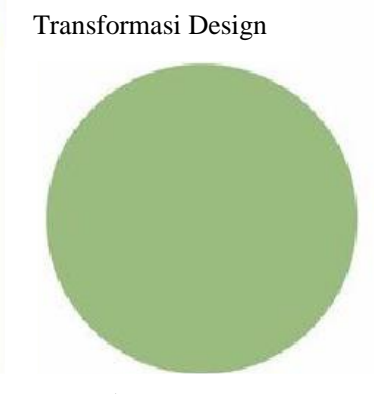

Tahap 1

Transformasi dari bentukan utuh yang mengambil dari center site.

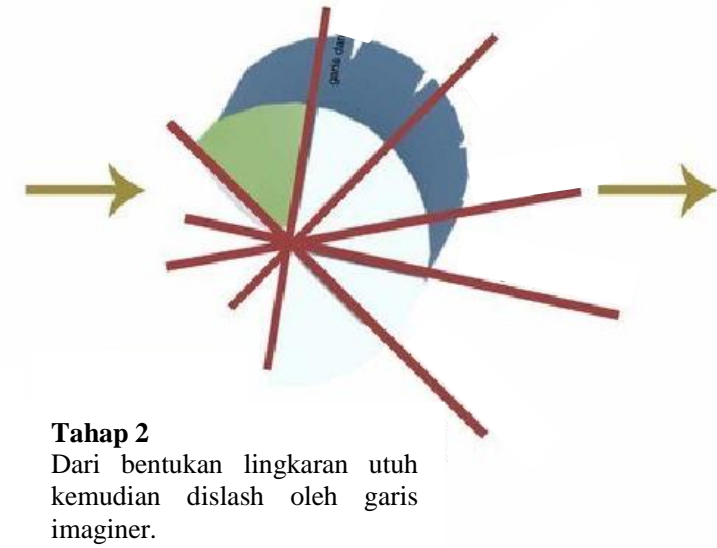

imaginer.

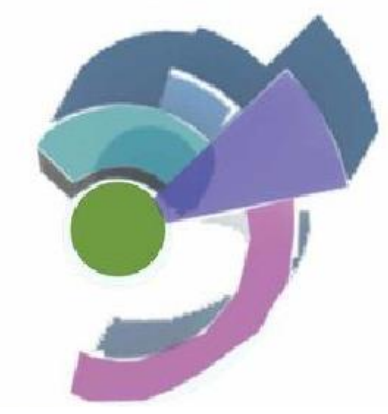

Tahap 3

Bentukan slash sesudah dipotong menggunakan garis imaginer dan dibagi menjadi 4 bentukan

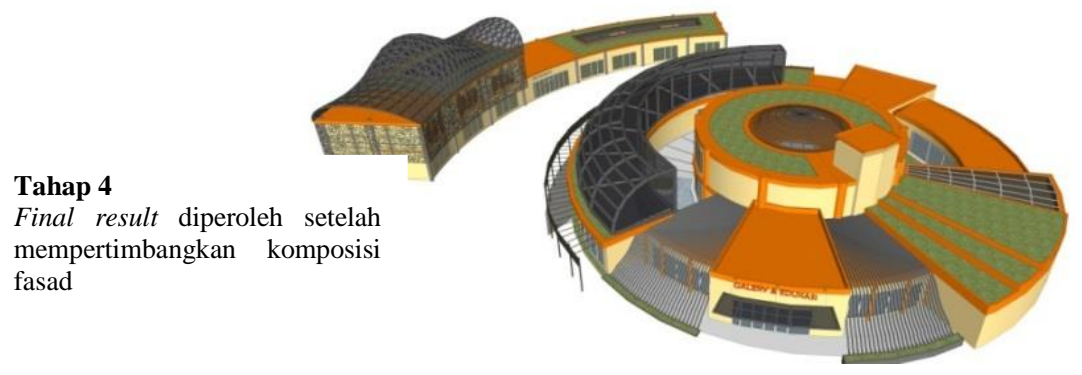

Gambar 7. Transformasi Tatanan Bentuk

\subsection{Konsep Mikro (Tatanan Ruang)}

Hasil rancangan merupakan implementasi dari konsep ruang yang mampu menjadi wadah kegiatan seperti tempat industri tempat untuk memproduksi. Penyediaan wadah kegiatan dilakukan dengan cara menyediakan berbagai macam fasilitas untuk mempromosikan atau memamerkan hasil karya bordir yang telah diproduksi. Semua ruang juga pada bangunan akan disesuaikan dengan kondisi lingkungan. Di bawah ini terdapat ruang lobby yaitu tempat untuk menunggu, ada juga tepat informasi dan sebelah kanan menggambarkan ruang produksi secara komputer.
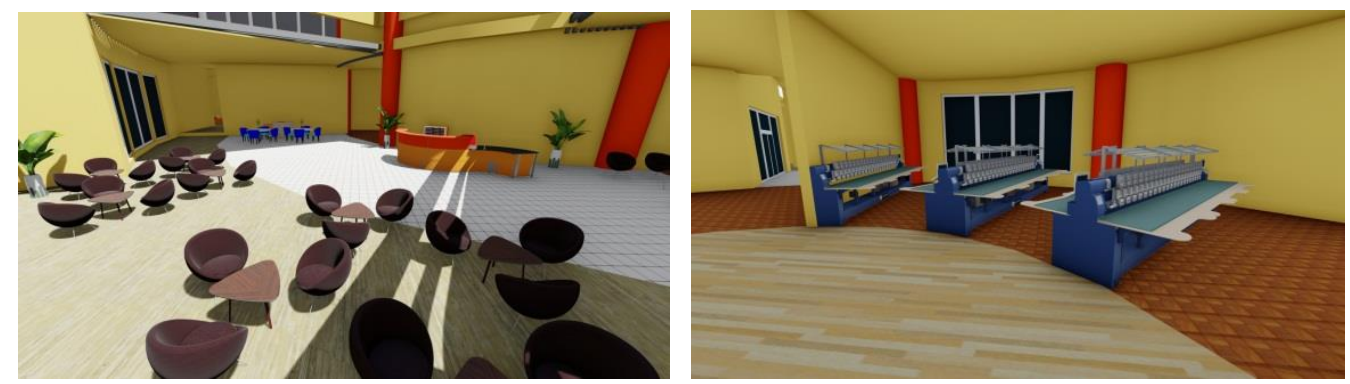

Gambar 8. (kiri) Ruang Lobby; dan (kanan) Ruang Produksi Bordir 


\section{Kesimpulan}

Sentra bordir merupakan sebuah gedung pameran dan pertunjukan karya kerajinan bordir, dimana bertujuan menampung seluruh kegiatan pelaku industri bordir dan dibuatkan suatu bangunan untuk mengembangkan industri bordir skala rumahan menjadi industri bordir skala besar yaitu dengan memberikan wadah atau tempat untuk produksi dan pemasaran hasil kerajinan serta adanya aktivitas lain diantaranya adalah pusat promosi, informasi, budaya edukasi. Sebagai salah satunya industri bordir, hasil produk bordir ini tidak hanya di jual dalam kawasan Kota Bangil saja tetapi juga dijual di kota lain, bahkan dipasarkan ke Pulau Jawa hingga ke luar negeri sehingga menjadi salah satu andalan sektor ekonomi di Kota Bangil. Tujuan dengan adanya proyek ini diharapkan mampu meningkatkan ukm yang ada di Kabupaten Pasuruan. Selain itu diharapkan bentuk bangunannya nanti bisa menarik minat wisatawan untuk mengunjungi area ini dengan kmegahannya, karena lokasi tapak yang dipilih juga strategis dan tidak jauh dari pusat alun - alun Bangil.

\section{Referensi}

Ardiyanti, L., Suryadi, S., \& Setyowati, E. (2015). Strategi Pemberdayaan Pengrajin (Studi pada Asosiasi Pengusaha Bordir Kelurahan Pogar Kecamatan Bangil dan Dinas Perindustrian dan Perdagangan Kabupaten Pasuruan). Jurnal Administrasi Publik (JAP), 3(5), 733-738. http://administrasipublik.studentjournal.ub.ac.id/index.php/jap/article/view/852

Budiastuti, E. (2013). Teknik Bordir Sasak. Jurnal Ilmiah WUNY. https://doi.org/10.21831/jwuny.v15i1.3532

Prihatina, Y. I. (2011). Bunga Sedap Malam sebagai Sumber Inspirasi Motif Bordir Bangil. In M. A. Jerusalem \& M. Harish (Eds.), Prosiding Pendidikan Teknik Boga Busana 2011 "Wonderful Indonesia” (pp. 1-8). PTBB FT UNY. https://journal.uny.ac.id/index.php/ptbb/article/view/30756

Vale, B., \& Vale, R. (1996). Green Architecture: Design For A Sustainable Future. Thames and Hudson Ltd. 